\title{
Effect of Rendering Temperature on Collagen Content from the Poultry Skin
}

\author{
Deepali Tanaji Sakunde, Rajiv Ranjan Kumar", Sagar Chand, Pratima Raypa, Prince Devadason, \\ Mukesh Gangwar, Pranav Chauhan, Somesh Meshram and Sanjod Kumar Mendiratta
}

\author{
Division of Livestock Products Technology, ICAR-IVRI, Izatnagar, U.P., INDIA \\ "Corresponding author: RR Kumar; E-mail:dr_rajivranjan@yahoo.com
}

Received: 08 June, 2020

Revised: 22 Sept., 2020

Accepted: 28 Sept., 2020

\begin{abstract}
While looking for an alternate source of commercial collagen the deserted poultry sleeves from wet poultry market appears promising. The present study was envisaged with objective of evaluating effect of the rendering regime on quantity of collagen in rendered poultry skin. The deserted poultry sleeves were custom processed for separation of feathers from skin. The skin was subjected to different rendering temperatures viz: 40,50 and $60^{\circ} \mathrm{C}$ for $2 \mathrm{hr}$. The yield of rendered fat, fat recovery rate, amount of defatted skin, hydroxyproline and collagen content in differently rendered skin were quantified to know the effect of rendering regime. Results revealed a gradual increase in yield of rendered fat and fat recovery rate with increase in temperature, while the amount of defatted skin, hydroxyproline and collagen content in rendered skin decreased with increase in rendering temperature. The yield of rendered fat at 40,50 and $60^{\circ} \mathrm{C}$ rendering temperature were $25.50 \%, 30.97 \%$ and $35.08 \%$ with corresponding fat recovery rates of $61.59 \%, 74.80 \%$ and $84.74 \%$, respectively. The hydroxyproline content was highest in skin processed at $40^{\circ} \mathrm{C}$ and least in skin rendered at $60^{\circ} \mathrm{C}$. The percentage recovery of collagen from skin rendered at $40^{\circ} \mathrm{C}, 50^{\circ} \mathrm{C}$ and $60^{\circ} \mathrm{C}$ were $96.37 \%, 77.22 \%$ and $62.01 \%$,respectively. The study indicated that dry rendering at $40^{\circ} \mathrm{C}$ temperature is optimal for rendering of fat while processing the poultry skin for extraction of valuable collagen.
\end{abstract}

\section{HIGHLIGHTS}

(0 Separated Skin from poultry sleeves can be an alternate source of valuable collagen.

0 The poultry skin can be optimally dry rendered for quality collagen besides usual fat.

(0 The increase in dry rendering temperature leads to increased loss of collagen but higher yield of fat.

(0 Rendering at $40^{\circ} \mathrm{C}$ temperature is better while processing the poultry skin for valuable collagen.

Keywords: Collagen, Dry rendering, Hydroxyproline, Poultry skin, Rendered fat

India has emerged as the $4^{\text {th }}$ largest broiler producer in the world. Indian poultry sector has evolved into an effervescent agribusiness spurred by domestic economic growth and consumption dynamics (Rana et al., 2017). Poultry production of India has been rising at an annual rate of around $8 \%$ (BAHS, 2019) and resulted in a lively agri-business with an annual turnover of ₹ 20,000 Crores. High consumption of poultry meat in the country leads to production of a considerable amount of chicken skin and feathers as a waste. These under utilized deserted poultry sleeves from wet market/ retailer shops leads to economical and nutritional losses besides environmental pollution. This large quantity of chicken skin can be utilized to produce collagen, which is having different applications in various industries like pharmaceuticals, biomedical materials, cosmetics and food industry (Singh et al., 2011; Jeong et al., 2013; Lafarga and Hayes, 2014; Liang et al., 2014; Silva et al., 2014). The usual procedure for extraction of valuable collagen involves defatting, removal of non-collagenous proteins from skin, demineralization, isolation of collagen followed by its purification. Various

How to cite this article: Sakunde, D.T., Kumar, R.R., Chand, S., Raypa, P. Devadason, P., Gangwar, M., Chauhan, P., Meshram, S. and Mendiratta, S.K. (2020). Effect of rendering temperature on collagen content from the poultry skin. J. Anim. Res., 10(5): 705-709.

Source of Support: None; Conflict of Interest: None 
attempts have been made for isolation of collagen from poultry skin (Cliche et al., 2003; Munasinghe et al., 2014; Arunmozhivarman et al., 2017; Munasinghe and Schwarz, 2017), however the process for optimization of collagen extraction procedures from poultry skin is still evolving leading to the use of bovine as largest source of collagen. Therefore, the present study was aimed to optimize the rendering temperature of poultry skin intended for collagen extraction by evaluating its effect on the yield of collagen from deserted poultry skin.

\section{MATERIALS AND METHODS}

Poultry sleeves collected from local retail shop, were washed and de-feathered manually after overnight soaking in vinegar solution ( $4 \%$ acetic acid), packed in a medium density polyethylene bags and frozen at $-20^{\circ} \mathrm{C}$. Frozen poultry skin was minced by $4 \mathrm{~mm}$ plates and homogenized for 2-3 $\mathrm{min}$ in a mixer grinder. This minced skin was rendered at temperature of $40^{\circ} \mathrm{C}, 50^{\circ} \mathrm{C}$ and $60^{\circ} \mathrm{C}$ for 2 hours in a locally designed electrically heated dry rendering machine. The rendered fat i.e. liquid phase of low density is separated by using muslin cloth and pressing it for one hour by applying pressure @ $1 \mathrm{~kg} / \mathrm{cm}^{2}$ and further separated from the high-density liquid phase with the help of a centrifuge machine at $5000 \mathrm{rpm}$ for 10 min. The amount of fat as well as the yield of collected rendered skin were recorded.

\section{Proximate analysis}

In order to rule out the variation due to initial stock of skin, moisture, fat, total protein and ash content of feathered skin were determined according to approved methods (AOAC, 1995). For moisture determination, samples were dried to constant weight in hot air oven at $100^{\circ} \mathrm{C}$ for $16 \mathrm{hr}$. Total protein in poultry skin was determined by the Kjeldahl method. For ash determination, samples were placed in a muffle furnace at a final temperature of $600^{\circ} \mathrm{C}$ for $6-8$ hour. Total fat was determined for each sample using a Soxhlet fat extraction assembly. The skins with almost similar values for proximate parameters were included in study.

\section{Yield of rendered fat}

The percentage yield of rendered out fat was calculated as below:
Yield of rendered fat $(\%)=$

$$
\frac{\text { Yield of rendered fat in gm }}{\text { Initial weight of the poultry skin }} \times 100
$$

\section{Percentage yield of left out rendered skin}

It was calculated as below:

Yield of rendered skin $(\%)=$

$$
\frac{\text { Yield of rendered skin }}{\text { Initial weight of the poultry skin }} \times 100
$$

\section{Fat Recovery Rate}

It was calculated as below:

Fat recovery rate $(\%)=$

$$
\frac{\text { Percentage yield of rendered fat }}{\text { Percentage fat in poultry skin }} \times 100
$$

\section{Percentage loss of dense liquid phase}

It was calculated by subtracting the sum of percentage yield of rendered fat and percentage yield of rendered skin from hundred.

\section{Hydroxyproline estimation}

The hydroxyproline contents in skin was analysed by using Bergamns and Loxley (1963) method with slight modifications. The $50 \mathrm{mg}$ skin sample was hydrolysed using $2 \mathrm{~mL}$ of $6 \mathrm{~N}$ HCL in an autoclave at $121^{\circ} \mathrm{C}$ temperature and $15 \mathrm{lbs}$ pressure for 1.5 hour. The hydrolysed sample was centrifuged and clear supernatant was neutralized with $2 \mathrm{~N}$ sodium hydroxide. Neutralized sample $(0.1 \mathrm{~mL})$ was mixed thoroughly with isopropanol $(0.2 \mathrm{~mL})$ in a eppendorf tube. Oxidant solution $0.1 \mathrm{~mL}$ (mixture of $7 \%(\mathrm{w} / \mathrm{v})$ chloramine $\mathrm{T}$ and acetate/ citrate buffer, $\mathrm{pH} 6$ at a ratio of 1:4 (v/v)) was added and mixed thoroughly. Ehrlich's reagent solution $1.3 \mathrm{~mL}$ [mixture of $2 \mathrm{~g}$ of p-dimethylaminebenzaldehyde in $3 \mathrm{ml}$ of $60 \%$ perchloric acid $(\mathrm{w} / \mathrm{v})$ and isopropanol at a ratio of $3: 13$ $(\mathrm{v} / \mathrm{v})]$ was added. The solution was agitated and heated at $60^{\circ} \mathrm{C}$ for $25 \mathrm{~min}$ in a water bath and cooled for 2-3 minutes under running water. Finally, absorbance was measured 
against distilled water as blank at $558 \mathrm{~nm}$. Hydroxyproline concentrations ranging from 2 to $12 \mathrm{ppm}$ were used to plot a standard curve, concentration of hydroxyproline were expressed as hydroxyproline content in $\mathrm{mg} / \mathrm{gm}$ of the poultry skin.

\section{Collagen estimation}

Hydroxyproline content was converted to collagen content using a factor of 7.57 (Bonifer and Froning et al., 1996).

Collagen content in the skin $(\mathrm{mg} / \mathrm{gm})=$ Hydroxyproline content $(\mathrm{mg} / \mathrm{gm}) \times 7.57$

\section{Harnessed percentage collagen from poultry skin}

It was calculated by multiplying the collagen content of rendered skin with yield percentage of rendered skin.

\section{Percent recovery of collagen from rendered skin}

It was calculated as below:

Percent recovery of collagen $(\%)=$

Collagen content of rendered skin $x$

$$
\begin{aligned}
& \text { yield of rendered skin } \\
& \text { initial weight of poultry skin }
\end{aligned}
$$

Collagen content of poultry skin $\times$ initial weight of poultry skin

\section{Percentage loss of collagen in dense liquid phase}

It was calculated by subtracting the percent recovery of collagen in rendered skin from 100 .

\section{STATISTICAL ANALYSIS}

Duplicate samples were taken for each parameter and 3 trials were conducted for each experiment. Total six observations $(n=6)$ were recorded to ensure consistency of the results. The results were analyzed statistically for variance and Least Significant Difference (LSD) test as per Snedecor and Cochren (1989). Means were compared by using Duncan's Multiple Range test (Duncan, 1995). Statistically analyzed data using SPSS software version 20 was tabulated and interpreted.

\section{RESULTS AND DISCUSSION}

The measured proximate composition parameters for poultry skin to ensure uniformity of the stock skin material were moisture $46.87 \% \pm 0.36$; fat $41.40 \% \pm 0.13$; protein $11.23 \% \pm 0.33$ and ash $0.28 \pm 0.01 \%$ on wet weight basis. Moreover, the hydroxyproline content, collagen content and percentage total collagen of the poultry skin were estimated as $4.67 \pm 0.01 \mathrm{mg} / \mathrm{gm}, 35.35 \pm 0.06 \mathrm{mg} / \mathrm{gm}$ and $3.54 \% \pm 0.01$ on wet weight basis, respectively. Osburn and Mandigo (1998), also reported proximate composition of chicken skin as $49.57 \%$ moisture, $41.32 \%$ fat and 9.22\% protein. Bonifer and Froning (1996) recorded approximately 50 percent fat and 3 percent of collagen content in a broiler skin. Cliché et al. (2003) observed 3.5\% \pm 0.3 total collagen in skin of commercial broilers. The variation in fat content of poultry skin may be attributed to differences in stock. In our case it was deserted sleeves from broiler birds. The percentage collagen content was almost similar.

Table 1: Effect of different rendering temperature on yield of rendered out fat, yield of rendered skin and recovery of rendered fat $($ Mean \pm SE)

\begin{tabular}{llll}
\hline $\begin{array}{l}\text { Rendering } \\
\text { Temperature } \\
\left({ }^{\circ} \mathbf{C}\right)\end{array}$ & $\begin{array}{l}\text { Yield of } \\
\text { Rendered Fat } \\
(\%)\end{array}$ & $\begin{array}{l}\text { Yield of } \\
\text { Rendered } \\
\text { Skin (\%) }\end{array}$ & $\begin{array}{l}\text { Recovery Rate } \\
\text { of Rendered } \\
\text { Fat (\%) }\end{array}$ \\
\hline 40 & $25.50^{\mathrm{a}} \pm 0.18$ & $48.33^{\mathrm{c}} \pm 0.21$ & $61.59^{\mathrm{a}} \pm 0.44$ \\
50 & $30.97^{\mathrm{b}} \pm 0.22$ & $40.92^{\mathrm{b}} \pm 0.33$ & $74.80^{\mathrm{b}} \pm 0.55$ \\
60 & $35.08^{\mathrm{c}} \pm 0.12$ & $35.75^{\mathrm{a}} \pm 0.25$ & $84.74^{\mathrm{c}} \pm 0.73$ \\
\hline
\end{tabular}

$\mathrm{n}=6$, Mean $\pm \mathrm{S} . \mathrm{E}, \mathrm{a}, \mathrm{b}, \mathrm{c}$ mean values within column with different superscripts are significantly different $(\mathrm{P} \leq 0.05)$.

Table 1 shows the yield of rendered fat, yield of rendered skin, and percentage recovery of rendered fat after dry rendering of poultry skin at 40,50 and $60^{\circ} \mathrm{C}$. The rendered fat yields were $25.50 \% \pm 0.18,30.97 \% \pm 0.22$ and $35.08 \%$ \pm 0.12 with corresponding percentage recovery of fat as $61.59 \% \pm 0.44,74.80 \% \pm 0.55$ and $84.74 \% \pm 0.73$ at 40 , 50 and $60^{\circ} \mathrm{C}$ of rendering temperature, respectively. The results clearly indicate significant increase in the yield and recovery of rendered fat with increasing the rendering temperature. Higher temperature facilitates melting of fat and its easy removal from skin tissues. Cliché (2003) also reported the fat recovery as 78 and $85 \%$ from broilers skin during dry rendering at 40 and $60^{\circ} \mathrm{C}$ temperature. 
Cheng et al. (1993) cited that yield of rendered fat from abdominal fat tissue increased with increase in rendering temperature. The yield of rendered skin at 40,50 and $60^{\circ} \mathrm{C}$ of dry rendering temperature was $48.33 \% \pm 0.21,40.92 \%$ \pm 0.33 and $35.75 \% \pm 0.25$, respectively. The yield of dry rendered skin was negatively correlated with the yield of rendered fat at different rendering temperature. Similar results were reported by Piette et al. (2001).

Table 2: Effect of different rendering temperature on hydroxyproline and collagen content of rendered poultry skin, percent recovery of collagen in rendered skin and percent loss of collagen in the dense liquid phase(Mean $\pm \mathrm{SE}$ )

\begin{tabular}{llll}
\hline \multirow{2}{*}{ Parameters } & \multicolumn{3}{c}{ Rendering Temperature } \\
\cline { 2 - 4 } & $\mathbf{4 0}^{\circ} \mathbf{C}$ & $\mathbf{5 0}^{\circ} \mathbf{C}$ & $\mathbf{6 0}^{\circ} \mathbf{C}$ \\
\hline Hydroxyproline Content in rendered & $9.31^{\mathrm{c}} \pm$ & $8.81^{\mathrm{b}} \pm$ & $8.10^{\mathrm{a}} \pm$ \\
skin (mg/gm) & 0.05 & 0.07 & 0.07 \\
Collagen Content in rendered skin & $70.49^{\mathrm{c}} \pm$ & $66.70^{\mathrm{b}} \pm$ & $61.33^{\mathrm{a}} \pm$ \\
$(\mathrm{mg} / \mathrm{gm})$ & 0.36 & 0.51 & 0.55 \\
Harnessed percentage collagen from & $3.41^{\mathrm{c}} \pm$ & $2.73^{\mathrm{b}} \pm$ & $2.19^{\mathrm{a}} \pm$ \\
poultry skin & 0.02 & 0.04 & 0.02 \\
Percent recovery of collagen from & $96.37^{\mathrm{c}} \pm$ & $77.22^{\mathrm{b}} \pm$ & $62.01^{\mathrm{a}} \pm$ \\
rendered skin & 0.36 & 1.17 & 0.52 \\
Percentage loss of collagen in dense & $3.63^{\mathrm{a}} \pm$ & $22.78^{\mathrm{b}} \pm$ & $37.99^{\mathrm{c}} \pm$ \\
liquid phase & 0.36 & 1.17 & 0.52 \\
\hline
\end{tabular}

$\mathrm{n}=6$, Mean \pm S.E, ${ }^{\mathrm{a}, \mathrm{b}, \mathrm{c}}$ mean values within rows with different superscripts are significantly different $(\mathrm{P} \leq 0.05)$.

Table 2 shows hydroxyproline and collagen content in rendered poultry skin, percentage recovery of collagen from rendered skin and percent loss of collagen in the dense liquid phase after dry rendering of poultry skin at 40,50 and $60^{\circ} \mathrm{C}$. The hydroxyproline content of rendered poultry skin was $9.31 \pm 0.05 \mathrm{mg} / \mathrm{gm}, 8.81 \pm 0.07 \mathrm{mg} / \mathrm{gm}$ and $8.10 \pm 0.07 \mathrm{mg} / \mathrm{gm}$ whereas, calculated collagen contents were $70.49 \pm 0.36 \mathrm{mg} / \mathrm{gm}, 66.70 \pm 0.51 \mathrm{mg} / \mathrm{gm}$ and 61.33 $\pm 0.55 \mathrm{mg} / \mathrm{gm}$ of rendered skin subjected to heat treatment of 40,50 and $60^{\circ} \mathrm{C}$, respectively. Hydroxyproline content and collagen content of poultry skin were recorded highest after rendering at $40^{\circ} \mathrm{C}$. The total collagen content was $3.41 \% \pm 0.02,2.73 \% \pm 0.04$ and $2.19 \% \pm 0.02$ and the percent recovery of collagen was $96.37 \% \pm 0.36$, $77.22 \% \pm 1.17$ and $62.02 \% \pm 0.52$ from the poultry skin subjected to rendering at 40,50 and $60^{\circ} \mathrm{C}$, respectively. However, percentage of collagen lost in dense liquid phase was $3.63 \% \pm 0.36,22.78 \% \pm 1.17$ and $37.99 \% \pm$
0.52 for the skin rendered at 40,50 and $60^{\circ} \mathrm{C}$. The reported denaturation temperature of chicken skin collagen in solution is $41^{\circ} \mathrm{C}$ (Burjanadze, 1982). Hence, application of higher temperatures $\left(50^{\circ} \mathrm{C}\right.$ and $\left.60^{\circ} \mathrm{C}\right)$ during rendering of poultry skin might have led to denaturation of the collagen protein by breaking of inter and intra-molecular bonds in present case resulting in loss of gelled collagen into dense liquid phase. Cliché et al. (2003) reported recovery of $97.1 \%$ collagen in a solid phase (rendered skin) at $40^{\circ} \mathrm{C}$ with preservation of structural integrity of collagen molecule due to absence of gelation, while at $60^{\circ} \mathrm{C}$ recovery rate of collagen was only $67.1 \%$. Fig. 1 shows negative correlation (correlation coefficient $[\mathrm{R}]=$ $-0.99)$ between the recovery rate of rendered fat $(\%)$ and percent recovery of collagen from the poultry skin after rendering at 40,50 and $60^{\circ} \mathrm{C}$ temperature.

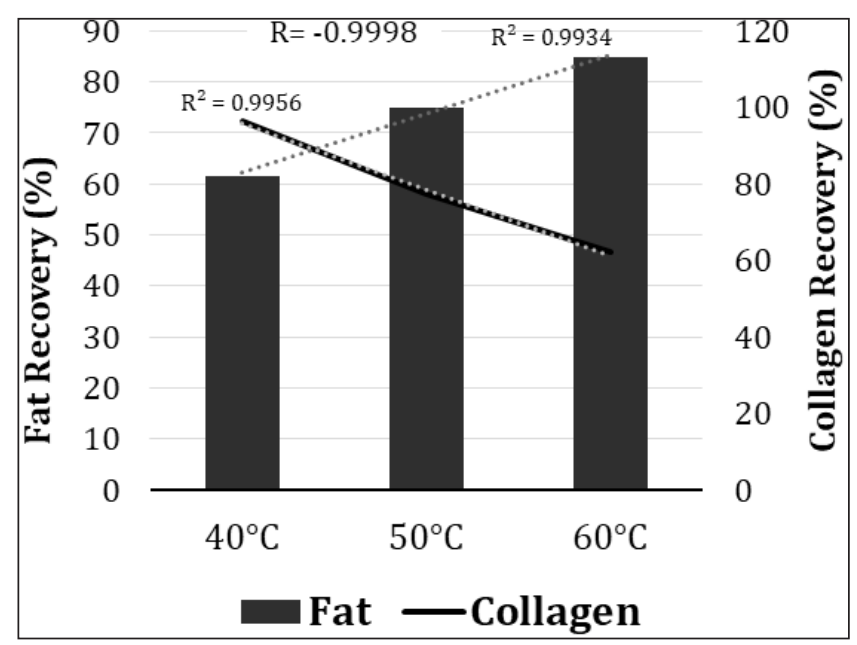

Fig. 1: Correlation between recovery rate of rendered fat (\%) and percent recovery of collagen from the poultry skin after rendering at different temperature

\section{CONCLUSION}

Chicken skin is economically viable source of collagen. Highest recovery of collagen $96.37 \% \pm 0.54$ was obtained at $40^{\circ} \mathrm{C}$ of dry rendering temperature with recovery of $61.59 \% \pm 0.44$ rendered chicken fat. Moreover,increase in rendering temperature showed decrease in percentage recovery of collagen in rendered skin. Hence, rendering of chicken skin at $40^{\circ} \mathrm{C}$ can be followed for extraction of collagen efficiently. This work demonstrated the significant effect of rendering temperature on the quantity of collagen present in rendered poultry skin. 


\section{ACKNOWLEDGEMENTS}

The authors would like to express gratitude and thankfulness to MoFPI, Govt. of India, New Delhi and ICAR-IVRI, Izatnagar, U. P. for providing funding and support.

\section{REFERENCES}

A.O.A.C. 1995. Official Methods of Analysis of AOAC International. $16^{\text {th }}$ Edn. Association of Official Analytical Chemist International. Arlington, USA.

Arunmozhivarman, K., Robinson, J.J., Abraham, V. Apparao and Parthiban, M. 2017. Extraction and molecular characterization of collagen from poultry meat processing by-product (Chicken Skin). Int. J. Pure App. Biosci., 5(5): 1085-1091.

BAHS. 2019. Basic Animal Husbandry Statistics, 2018-19. Department of Animal Husbandry, Dairying and Fisheries. Ministry of Agriculture and Farmers Welfare, Government of India.

Bergman, I. and Loxley, R. 1963. Two improved and simplified methods for the spectrophotometric determination of hydroxyproline. Anal. Chem., 35(12): 1961-1965.

Bonifer, L.J. and Froning, G.W. 1996. Chicken skin composition as affected by aqueous washings. J. Food Sci., 61: 895-898.

Burjanadze, T.V. 1982. Evidence for the role of 4-hydroxyproline localized in the third position of the triplet (Gly-X-Y) in adaptational changes of thermos-stability of a collagen molecule and collagen fibrils. Biopolymers, 21: 1489-1501.

Cheng, H.H., Lee, M.F., Chang, Y.S., Gei, S.B. and Shieh, M.J. 1993. Nutrient, stability and sensory evaluation of chicken fat. J. Chin. Nutr. Soc., 18: 209-22.

Cliche, S., Amiot, J., Avezard, C. and Garepy, C. 2003. Extraction and characterization of collagen with or without telopeptides from chicken skin. Poult. Sci., 82: 503-509.

Duncan D.B. 1995. Multiple range and multiple F tests. Biomet., 11: $1-42$.
Jeong, H.S., Venkatesan, J. and Kim, S.K. 2013. Isolation and characterization of collagen from marine fish (Thunnus obesus). Biotechnol. Bioprocess Eng., 18(6): 1185-1191.

Lafarga, T. and Hayes, M. 2014. Bioactive peptides from meat muscle and by-products: generation, functionality and application as functional ingredients. Meat Sci., 98(2): 227239 .

Liang, Q., Wang, L., Sun, W., Wang, Z., Xu, J. and Ma, H. 2014. Isolation and characterization of collagen from the cartilage of Amur sturgeon (Acipenser schrenckii). Process Biochem., 49(2): 318-323.

Munasinghe, K.A., Schwarz, J.G. and Nyame, A.K. 2014. Chicken collagen from law market value by-products as an alternate source. J. Food Process., 2014: 6.

Munasinghe, K.A and Schwarz, J.G. 2017. Rooster collagen extracts from rooster by-products. J. Nutr. Health Food Eng., 7(3): 00239.

Osburn, W.N. and Mandigo, R.W. 1998. Reduced-fat bologna manufactured with poultry skin connective tissue gel. Poult. Sci., 77: 1574-1584.

Piette, G., Hundt, M., Jacques, L. and Lapointe, M. 2001. Influence of extraction temperature on amounts and quality of rendered chicken fat recovered from ground or homogenized skin. Poult. Sci., 80(4): 496-500.

Rana, D., Katoch, S., Mane, B.G., Rani, D. and Sankhyan, V. 2017. Carcass Characteristic and Physicochemical Properties of Broiler Chicken Meat Supplemented with Azolla pinnata. J. Animal Research, 7(6): 1035-1041.

Silva, T.H., Moreira-Silva, J., Marques, A.L.P.P., Domingues, A., Bayon, Y. and Reis, R.L., 2014. Marine origin collagens and its potential applications. Mar. Drugs., 12(12): 5881-5901.

Singh, P., Benjakul, S. and Maqsood, S. 2011. Isolation and characterisation of collagen extracted from the skin of striped catfish (Pangasianodon hypophthalmus). J. Food Chem., 124(1): 97-105.

Snedecor, G.W. and Cochran, W.G. 1989. Statistical Methods. $8^{\text {th }}$ edn. IOWA state University Press, Ames, IOWA. 
